\title{
New England Classical Journal
}

Volume 48 | Issue 2

$12-20-2021$

\section{What's with Caesar and the Third Person in the Gallic Wars?}

Ruth Breindel

rbreindel@gmail.com

Follow this and additional works at: https://crossworks.holycross.edu/necj

Part of the Classics Commons

\section{Recommended Citation}

Breindel, Ruth (2021) "What's with Caesar and the Third Person in the Gallic Wars?," New England Classical Journal: Vol. 48 : Iss. 2, 1-11.

https://doi.org/10.52284/NECJ.48.2.article.breindel

This Article is brought to you for free and open access by CrossWorks. It has been accepted for inclusion in New England Classical Journal by an authorized editor of CrossWorks. 


\title{
Articles
}

\section{What's with Gaesar and the Third Person in the Gallic Wars?}

\author{
RUTH L. BREINDEL
}

\begin{abstract}
While we say that the Gallic Wars were written by Caesar, they were really written by the scribes. The thesis of this paper is that they used the third person singular to refer to Caesar, since they were taking down dictation and would not use "I/we," as they were not the ones who had done the action. This use of the third person is attested to in Greek authors, and Caesar obviously was pleased with how it sounded; while he had the last word on the subject, it's the scribes who deserve the credit for style.
\end{abstract}

Keywords: Julius Caesar, Gallic War, scribes, dictation, Third person, stylistics

Who were the Scribes?

Caesari cum id nuntiatum esset eos per provinciam nostram iter facere conari, maturat ab urbe proficisci et quam maximis potest itineribus in Galliam ulteriorem contendit et ad Genavam pervenit ... ubi de eius adventu Helvetii certiores facti sunt, legatos ad eum mittunt ... (BG 1.7)

When it had been reported to Caesar that they had tried to march through our province, he hastens to set out from the city and by forced marches he hastens into further Gaul and arrives at Geneva ... When the Helvetians were informed about his arrival, they send envoys to him

This is our first view of Caesar in the Gallic Wars; up to now, it has all been geography and commentary on the Gauls, and especially the Helvetians. We first meet Caesar in the dative, as the recipient of news; Caesar then continues to be the third person singular subject in the rest of the sentence, with maturat, contendit, pervenit. In the second sentence, Caesar becomes eius and eum, again third person singular, not the subject but the object.

Everyone knows that Caesar had a beautiful writing style in the Gallic Wars: clear, concise, and full of information. There are many theories about why he uses the third person, some quite torturous, which I will go into shortly. However, I believe this is putting the cart before the horse; the workhorse here, the one who is deciding on the Latin style (with Caesar's approval, of course), is the scribe.

Caesar did decide what he wanted to say, but, as to who physically put the words down in actual writing, and how that influenced the choice of the words, we now turn to scribes. ${ }^{1}$ A general cannot sit and write down his thoughts; he is too busy taking care of everything. As Caesar states in Book 2.20.1 of the Gallic Wars:

Caesari omnia uno tempore erant agenda: vexillum proponendum, quod erat insigne, cum ad arma concurri 
oporteret; signum tuba dandum; ab opere revocandi milites; qui paulo longius aggeris petendi causa processerant arcessendi; acies instruenda; milites cohortandi; signum dandum.

All things had to be done at one time by Caesar: the banner had to be displayed, which was evident, when it was fitting to engage at arms; the signal had to be given by the trumpet; the soldiers had to be recalled from their work; those who had gone a little farther for the sake of seeking [items for the] ramparts had to be summoned; the battle line had to be drawn up; the soldiers had to be encouraged; the signal had to be given.

Caesar's use of scribes is attested to both by Plutarch (Life of Caesar 17.4) and Pliny the Elder (Natural History 7.25). Since Caesar couldn't physically write all this down, information was given to the scribes, who wrote it down.

Why "scribes" in the plural? Breindel (p. 257) states:

I came to this conclusion when teaching Book 1 of the Gallic

Wars. I noticed that there were great differences in the purpose expressions being used: the subjunctive or the gerund/ gerundive. I then went through all of Book 1, finding every example of ut / ne / qui etc. with the subjunctive as well as all the gerunds and gerundives.

After an exhaustive search of style in Book 1 of the Gallic Wars, focusing on the purpose clause using the subjunctive versus gerunds or gerundives, it is obvious that there were at least two or three scribes at work. For example, in chapters 8 through 17, there is not one use of the gerund/ive, but 8 of the subjunctive. In chapters 18 to 20 , there are two uses of the gerund/ive and one of the subjunctive. Chapters 21 to 37 do not have a single gerund/ive but instead 12 subjunctives. In chapters 38 to 42 , there is equal use of both constructions (4 each). Chapters 43 to 47 have 6 gerund/ives, and not one use of the subjunctive. Finally, chapters 49 to 53 are entirely subjunctive (6 uses). ${ }^{2}$ From this we can draw the conclusion that one scribe (or group) liked gerund/ives, another preferred the subjunctive, and the last would happily use either.

Thus, the final conclusion to that article:

... looking at the clumps of constructions, it would seem that either a huge amount of information was written down at one time as Caesar dictated, or that the scribe made his notes and later went over them and wrote the text.

So, to answer the question: who wrote the Gallic Wars? I suggest it was a collaboration between the scribes and Caesar, and not Caesar alone. ${ }^{3}$

Karen Carducci, discussing the use of the supine, agrees that the scribes made choices in the writing:

Since for purpose clauses, Caesar uses the gerundive with the preposition ad more often than the supine, however, as a search 
of the Library of Latin Texts, Series A reveals (144 instances), a scribe might have been less likely to change the commoner form of the gerundive to the supine, a form he encountered less frequently in Caesar's texts. If, on the other hand, he was attempting to correct the text he had in front of him, he would be more likely to change a syntactical usage from one he saw less often to one more familiar to him. That is, the scribe would be more likely to alter an original supine to a gerundive than vice versa. ${ }^{4}$

She goes on to elaborate:

By comparison with other kinds of purposes clauses, for example, $u t$ with the subjunctive, ad with the gerundive (144 instances according to Library of Latin Texts - Series A, henceforth LLT-A), or causa with the gerund(ive) (90 instances according to LLT-A), Caesar rarely uses the supine. $^{5}$

\section{How the Third Person Account Came About}

If we accept the important role of scribes, we can easily see how the third person came to be used by the scribes. When Caesar was dictating, for example, "When it was reported to me...," the scribe would naturally write "When it was reported to Caesar/him ...." Certainly nothing was reported to the scribe! When Caesar said, "When the Helvetians were informed about my approach," the scribe wouldn't write "my," since it wasn't his approach, but "his," eius, referring back to Caesar.

Even in a very emotional passage,

qua in re Caesar non solum publicas, sed etiam privatas iniurias ultus est, quod eius soceri L. Pisonis avum, L. Pisonem legatum, Tigurini eodem proelio quo Cassium interfecerant. (BG 1.12)

In which matter Caesar not only avenged public, but also private injustices, because the Tigurini had killed the grandfather of his fatherin-law L Piso, L Piso the lieutenant, in the same battle in which they had killed Cassius.

Where Caesar is avenging a private injustice, there is no deviation from the third person; it was not "I" the scribe who took revenge, but Caesar. Pelling, on the other hand, sees this as a distancing:

Even this early in the text-in fact, especially this early in the text, with the narrator signaling that the 'Caesar' of the text is not like other characters - we do not have to ask 'how does the narrator know what was in Caesar's mind?', because of course he knows. He has privileged access. $^{6}$

I do not agree with this view; while Pelling sees several Caesars in the story, I see only one. This is further discussed below.

\footnotetext{
Carducci 2018, 405

Carducci 2018, 406

Pelling 2013, 49; Nousek (YEAR), 230
} 
Who were these scribes? According to Purcell, ${ }^{7}$ there were four types of scribes who worked for the Roman magistrates. In addition, these men could hire themselves out to other people; they were trained for their specific purpose. This was also a way for men to rise in social status, as scribes were considered important. The poet Horace, "is said to have made his way back to a livelihood worthy of a Roman knight by buying a post as scriba quaestorius." In addition,

Despite being the son of a freedman from a Samnite town, Horace had been educated together with the offspring of the Roman elite, which earned him the equestrian post of tribunus militum in Brutus' army. Money, education and consequent social connections made for impressive social climbing. ${ }^{9}$

Certainly all the scribes were educated; they were often legati and came from the middle and upper classes, ${ }^{10}$ and surely had a reading knowledge of Greek in addition to their Latin. They had studied Thucydides and Xenophon, ${ }^{11}$ and knew that the use of the third person had the authority of the Greek masters on its side. They would have seen this as perfectly acceptable. Caesar who, we are told, spoke Greek effortlessly and was thoroughly familiar with Greek authors, would have been fine with this, too. After all, Hirtius, Caesar's legatus, wrote the $8^{\text {th }}$ book of the Gallic Wars! We also know that Titus Labienus was of equestrian rank and a tribune of the plebs (tribune was the lowest rank in the cursus honorum but definitely on the ladder). In addition, Best believes that the soldiers in the Roman army were literate. ${ }^{12}$

Riggsby actually starts down this path:

If the so-called third-person style is useful to Caesar, we may still ask whether he found it ready for use as a genre feature or whether it represents an innovation on his part. The direct evidence here is weak. ${ }^{13}$

Christopher Krebs also agrees:

But the greatest facilitator of misreading the commentaries is the thirdperson narrator; no one would have categorized them as history if they had been written in the first person, such as: "When these developments were reported to me, I decided. .."14

I have continued down this path to its end, stating that since the scribes wrote in the third person, and Caesar found it useful for so many reasons (perhaps as genre as Riggsby says, or to give historical accuracy, as Krebs believes), the direct evidence goes back to the work of the scribes. Certainly nothing would happen without Caesar's later agreement.

\footnotetext{
Purcell 2001, 649

Hartman 2020, 107. Here he quotes Suetonius, Horace 24.

Hartman 2020, 112

10 Best 1966, 126-7, where the eques is given the job of reading the tessera with the password or commands:

"When we then hear of a centurion and standard-bearer actually reading letters and poetry as a matter of course, the case for the literate Roman soldier is indeed strong from the time of Polybius."

11 Grillo 2011, 266

12 Best 1966, 122

13 Riggsby 2006, 67

14 Krebs 2019, 211
} 


\section{How About Other Aspects of Caesar's Style?}

Much has been written about Caesar's clear, concise writing. He was a skilled orator who was praised by many contemporaries. For example:

Cicero, in the Brutus, written in 46 BCE, twice discussed Caesar's oratorical style and concluded that Caesar was a great orator and didn't use an elaborate style.

Sallust, also a contemporary, said about Caesar - and Catiline - that Caesar was a great orator and quite smart.

Quintilian, who wrote his Institutiones in the first century CE, made two comments: first, that Caesar was a fiery speaker, just as he was a fiery general, and second, that his energy was remarkable.

Tacitus (late 1 st - early 2 nd century CE), who was a sharp commentator, stated in his Dialogue that he did not think Caesar's speeches were wonderful, but they were better than his poetry (that is so Tacitean - damning with faint praise). But he did agree with others that Caesar was brilliant, in both the Dialogue and Annales.

Pliny the Younger, Tacitus' contemporary, stated that Caesar belonged among the best orators.

Suetonius, a purveyor of gossip who never found a rumor he didn't repeat, a contemporary of Tacitus and Pliny, quoting Cicero, agreed that Caesar was brilliant.

Plutarch, the Greek contemporary of the above three writers, who was not interested in gossip, believed that Caesar could have been a great orator had he not desired politics above all.

Aulus Gellius, who wrote slightly later than the above group, commented in his Attic Nights that Caesar was brilliant.

Finally, Apuleius, a contemporary of Gellius, in his Apology, stated that Caesar's style showed warmth, not an attribute that we ordinarily attribute to Caesar.

Thus, according to the ancient authors, Caesar was a wonderful orator with brilliance and an exceptional style. He used a clear method of communication, which the scribes obviously followed carefully.

Modern commentators agree with this, and by using the fragments of Caesar's De Analogia, they view his style as a combination of various authors along with his own desire to be absolutely straight-forward. From the quote below, you can see that Caesar honored his predecessors, especially the Greeks as mentioned above, and therefore the style of writing which would use the $3^{\text {rd }}$ person singular in a report.

... Caesar seems to Romanize the suggestions that may have come to him from Philodemus and interpret the 'natural' element of style as the language and ethical qualities of the Scipionic age, a generation that helped to forge the identity of the Roman people. At the same time ... he is aware of language change and proposes a communicative system that is not archaizing but based on what he says are the most essential features of the Latin language, correctness and clarity. ${ }^{15}$

This is exactly Karen Carducci's point mentioned above: that the scribe would use the most common and natural forms, not something abstruse.

How about voice or agency in Caesar? Daniel Libatique defines it thus:

Possessing agency means that one's actions or words are not circumscribed by external limitations ... The agent does something, rather than allowing the status quo to remain static or waiting passively to be swept up into the

15 Garcea 2012, 124 
action of others. An agent has autonomy, exhibits control of his or her own actions, and executes those actions with intentionality. ${ }^{16}$

When looking at the first book of $B G$, the issue of voice or agency is obvious - it's Caesar all the time! At least 89 times he is in the nominative or implied nominative (as Caesar or as the continued subject of the verbs that follow), as the person in charge to whom information is brought (at least 9 times) and as the subject of the indirect statement (at least 11 times). Caesar is active and in command.

\section{Who is We?}

Sometimes, but rarely, the scribes got carried away by the action and used the form diximus.

Atuatuci, de quibus supra diximus ...(BG 2.29)

The Atuatuci, about whom we have spoken above ...

Here they are putting themselves into the action (another thing Caesar does very rarely) and reminding the reader that information had already been given - "we told you about this before." Certainly they would not say, "I told you about this before" - the scribe is, after all, the low man on the totem pole and would not put himself forward in any way.

Riggsby does not think that this "we" form is particularly important:

In both cases [use of "we" in 5.13.4 and 7.25.1] there is an ambiguity between two more or less idiomatic uses of "we" in Latin. On the one hand, it can stand in for the first-person singular (under circumstances that are not well understood,) and in fact the narrator does identify himself as "we" several times. If that is the case in either of these passages, then the narrator locates himself firmly as one of the Romans, Caesar being a prime candidate. On the other hand, Latin writing is ethnocentric enough that "we" can mean simply "the Romans ..."17

He continues in this vein: "There are several back-references to earlier segments of the text as well; all are brief and of forms like "as was said before" and "as we showed above." 18

Pelling takes a different tact with Avaricum:

In Bellum Gallicum we have the remarkable passage when we are told of an incident at Avaricum ( $B G$ 7.25.1) which happened as we watched: we have taken the view that it was memorable and should not be passed over in silence. 'We' rather than ' $I$ ', so the watching could have been done by any eye-witness (we will find something similar in Xenophon 47); but the 'we' who have thought this worth recording are surely a 'we' of authorship, so that we-Caesarians as providers of the material and we-Caesar as writer are melded together as constructors of the narrative. ${ }^{19}$

\footnotetext{
Libatique 2020, 2

Riggsby 2006, 150

18 Riggsby 2006, 154

19 Pelling 2013, 54
} 
I think that Riggsby is closer to the mark, in that the "we" is not especially important. On the other hand, as for Avaricum, the scribe was presumably there at the battle too, if we accept, as most do, that the book was written at the time of action, and not years later.

Another example, which I think is more to the point of Caesar and his scribes experiencing things together: "and there then occurred, before our very eyes, something which, being worth remembering, we believed should not be passed over" (accidit inspectantibus nobis, quod dignum memoria uisum praetereundum non existimauimus, $B G$ VII.25)

\section{Caesar's Audience}

Caesar's audience, according to various scholars, was both the educated elite ${ }^{20}$ of his group and the people who looked at public readings as entertainment.

How did Caesar reach the Roman People? Here we have to bear in mind a remarkable fact. In late-republican Rome historical narrative was popular entertainment. ${ }^{21}$ In addition, "the audience for a history expected a largely third-person narrative relating or extolling deeds and words." 22 Riggsby agrees:

In the Republic, the annual and collegial character of the magistracies would have made the first-person records not only impolitic but hardly comprehensible (amidst a sea of different "I's"). ${ }^{23}$

That, of course, is another reason not to say "I" - would the person reading this aloud want people to think that he had done what Caesar did? Surely not! ${ }^{24}$ How could one keep the various "I" people apart? Well, give it Caesar's name right then and there.

Historically, "the Roman victory texts customarily presented the general in the third person singular, naming his role as consul or imperator as a way of marking that victory had been accomplished in the name of Rome." ${ }^{25}$ Modesty is always useful!

\section{The Various Caesars}

One of the major discussions about Caesar's style with the third-person hinges on Caesar as narrator as well as Caesar as author or character. Here are the summaries, in chronological order, with a critique. This paper is only referencing the first 7 books of the Bellum Gallicum, not the Bellum Civile.

$$
\text { P. T. Eden }{ }^{26} \text { in } 1962 \text { had posited three "Caesars": }
$$

But Caesar is simultaneously the writer, the observer and the commander-in-chief; his own name opens the long period [BG II.25.12] and the whole narrative of the turmoil hangs on the significant thread: Caesar ... vidit ... vidit ... processit ... iussit.

\footnotetext{
${ }^{20}$ Hall 2009, 24. "But the remarkable fact is that in Caesar's close circle, most of the men we encounter are of free, indeed elevated, status, mostly politically active or prominent or ambitious in their own right, with, moreover, their own intellectual interests, or claims or pretensions to literary merit or fame..."

21 Wiseman 2009, Kimborough 2014, 13

22 Marincola 1997, 79

23 Riggsby 2006, 153

24 See my critique of Pelling below.

25 Östenberg 2013, 827

26 Eden 1962, 110
} 
He later goes on to state: “This suited Caesar's needs exactly: he would be his own most detached judge and expositor." 27

Andrew Riggsby sees two different Caesars: "The first person is used to refer to the narrator, but the general is always in the third person." 28

Christopher Pelling ${ }^{29}$ neatly sums up these various "Caesars":

... an air of impersonality, perhaps, or objectivity, or monumentality; the suggestion that this is the sort of thing that anyone can and should say about Caesar's achievement, not just the achiever himself, thus conveying 'a definitive account in the manner of a historian'; an impression of narratorial omniscience, masking any distinction between events that Caesar witnessed and those that he did not; a minimizing of his individuality and a 'bolstering of his role as Rome's agent'; or Peter Wiseman has suggested that others might be delivering Caesar's text in and around Rome and Italy, naturally then talking of what Caesar has done in the third person. ${ }^{30}$

Pelling does not like Wiseman's idea, although of course that is one of this paper's points, stating in footnote 33 that,

Wiseman (1998: 8 n.27): if the commentaries were written to be delivered by a speaker at a public meeting, narrating Caesar's exploits to the people, the third-person form was unavoidable. "Unavoidable" put this too strongly. If the deliverer was seen simply as an intermediary, a firstperson form would have seemed as natural as, say, the use of the first person in a governor's letter that was being read out. ${ }^{31}$

In this paper, I disagree with Pelling's criticism; as mentioned above, the reason for the third person was just that it was not the reader at the meeting who had done the deeds, but Caesar.

Pelling goes on to distinguish between 2 Caesars:

Let us begin with motive-statements: the way that Caesar the writer I-Caesar - so frequently sets out an intention or motive of Caesar the general, he-Caesar. ${ }^{32}$

Later in the same paper Pelling downplays the third person aspect:

So in this first panel of the text we immediately see that this is only a sort-of third-person narrative, a first-person-masquerading-as-thirdperson. There is no room here for a Reader B, innocently unaware of who was wielding the pen. The manner will be different when he-Caesar was not present, for instance, when the narrative of $B G 3$ describes the doings of Ser. Galba or Titurius Sabinus or P. Crassus (BG 3.1-6, $17-19,20-26){ }^{33}$

27 Eden 1962, 94

28 Riggsby 2006, 273

29 Pelling 2013, 48

30 Pelling 2013, 48

31 Pelling 2013, 48

32 Pelling 2013, 48

33 Pelling 2013, 51 
However, you can't have it both ways; either Caesar is doing a first person, by putting himself into the story, or a third person.

Hanson, in his MA Thesis, agrees with the concept of different Caesars:

Caesar the author makes a distinction between the narrator of the text and Caesar the character. The narrator makes asides (such as the everpresent "as we mentioned above") in the first-person, while Caesar the character is referred to in the third-person. ${ }^{34}$

Again, since the scribe is the one writing this, the "we," as I stated above, can include the scribe.

Kurt Raaflaub and Cynthia Damon give the most measured view of the various Caesars:

"... the way Caesar distances himself from "Caesar" writing about himself in the third person. This is not a strategy of dissociation - Caesar wants full credit for "Caesar's" achievements - but aims, rather, to give the reader the impression of seeing Caesar's achievements from the outside and not the inside, and against a backdrop of other characters rather than as the work's only "I." It is as though the author, and through him the reader, has achieved the kind of perspective on his achievements that permits evaluation against the parameters of collective and individual virtue discussed above. Both the title [Commentarii] and the third-person narrative have sometimes been taken as deliberately deceptive fictions. That they are fictions is true, but only in the sense that all writing, as verbal artifact, is fictional. That they were deliberately chosen seems certain [and not deceptive]."35

A somewhat nuanced view is mentioned by Ida Östenberg:

Now, as has been discussed by Batstone and Damon, Caesar by using the third person in his commentarii paradoxically manages to shape an intimate feeling of shared values that transmits a sense of 'us' to his readers. The recurrent character Caesar appears as an impersonal and distanced actor in the field, who fights for the good of Rome, and whose deeds appear as objective facts. This is an image of Caesar, omnipresent and highly successful, but still in the midst of equals. ${ }^{36}$

Here Caesar is present not in various personae (character, narrator, author), but more as the prime mover.

\section{Conclusion}

This view of several Caesars - as narrator, as author, as character - seems too complicated to me. Employing Occam's Razor, it is not necessary to break it down so much; it's so much simpler to understand that the scribe wrote in the third person, Caesar thought that was fine (whether because he wanted to be like the Greeks or to give more weight to history), and that's the end of the matter! Even the first-person usage can be attributed to a scribe who was present at the action. Giving credit to the scribes is bringing to the fore

34 Hanson 2015, 9

35 Damon 2019, xlviii - xlix

36 Östenberg 2013, 825-6 
a group that has never gotten enough notice or honor for its work. Let's change that now and grant the scribes recognition for their role in preserving history. ${ }^{37}$

emerita Moses Brown School rbreindel@gmail.com

\section{Works Cited}

Best, Edward E. 1966. "The Literate Roman Soldier.” The Classical Journal 62: 122-27. Breindel, Ruth L. 2016. "Who Wrote the Gallic Wars?” New England Classical Journal 43: 253-83.

Carducci, Karen L. 2018. "The First Supine in Bellum Gallicum and Bellum Civile: A Study of Caesar as Grammarian, Narrator, and Exemplum." Classical Philology 113: 404-22.https://doi.org/10.1086/699756

Eden, P. T. 1962. “Caesar's Style: Inheritance versus Intelligence.” Glotta 40: 74-117.

Garcea, Alessandro, and César Cayo Julio. 2012. Caesar’s De Analogia: Edition, Translation, and Commentary. Oxford: Oxford University Press.

Grillo, Luca. 2011. "Scribam Ipse De Me: The Personality of the Narrator in Caesar's Bellum Civile." American Journal of Philology 132: 243-71. https://doi.org/10.1353/ajp.2011.0013

Hall, Lindsay G.H. 2009. "Ratio and Romanitas in the Bellum Gallicum.” In Julius Caesar: the Artful Reporter, edited by Kathryn Welch, 11-43. Classical Press of Wales.

Hanson, Wesley J. 2015. A Literary and Narratological Reading of Titurius Sabinus and Quintus Cicero in Julius Caesar's Bellum Gallicum. University of Kansas.

Hartman, Benjamin. 2020. The Scribes of Rome: A Social and Cultural History of the Scribae. Cambridge University Press. https://doi.org/10.1017/9781108656917

Kimbrough, Timothy. 2014. The Contextual Audiences of Caesar's De Bello Gallico. The University of Tennessee-Knoxville, Honors Program.

Krebs, Christopher B. 2019. “Caesar the Historian.” In Raaflaub and Strassler, 210-13. Libatique, Daniel. 2020. "Verbal Agency in the Speech of Cremutius Cordus (Tacitus Annals 4.34-5)." New England Classical Journal: 47: 1-16.

Marincola, John. 1997. Authority and Tradition in Ancient Historiography. Cambridge University Press. https://doi.org/10.1017/CBO9780511584831

Nousek, Debra L. 2019. “The Gallic War as a Work of Literature.” In Raaflaub and Strassler, 229-235.

Östenberg, Ida. 2013. "Veni Vidi Vici and Caesar's Triumph.” The Classical Quarterly 63: 813-27. https://doi.org/10.1017/S0009838813000281

Pelling, Christopher. 2013. "Xenophon's and Caesar's Third-Person Narratives-Or are They?" In The Author's Voice in Classical and Late Antiquity, edited by Anna Marmodoro and Jonathan Hill, 39-73. Oxford University Press. https://doi. org/10.1093/acprof:oso/9780199670567.003.0003

Purcell, Nicholas. 2001. "The Ordo Scribarum: A Study in the Loss of Memory." Mélanges de l'École française de Rome Antiquité, 633-74. https://doi.org/10.3406/mefr.2001.9649

Raaflaub, Kurt A., and Cynthia Damon. 2017. "Caesar’s Life and Works.” In Raaflaub and Strassler, xxiii-lxiv.

Raaflaub, Kurt A. and Robert B. Strassler, eds. 2017. The Landmark Julius Caesar: The Complete Works: Gallic War, Civil War, Alexandrian War, African War, and Spanish War: In One Volume, with Maps, Annotations, Appendices, and Encyclopedic Index. New York: Pantheon Books._

37 This paper could not have come to fruition without the excellent advice and encouragement of Professor Timothy Joseph of the College of the Holy Cross. 
Riggsby, Andrew M. 2006. Caesar in Gaul and Rome: War of Words. University of Texas. https://doi.org/10.7560/713031

Rood, Tim. 2007. “The Development of the War Monograph: Memoir and Autobiography in Republican Rome." In A Companion to Greek and Roman Historiography Volume 1, edited by John Marincola, 266-74. Blackwell Publishing Ltd. https://doi.org/10.1002/9781405185110.ch11

Wiseman, T. P. 2009. "Publication of de Bello Gallico.” In Julius Caesar: the Artful Reporter, edited by Kathryn Welch, 1-10. Classical Press of Wales. 